\title{
Exploring entrepreneurial learning during formal business rescue processes: Insights from the South African experience
}

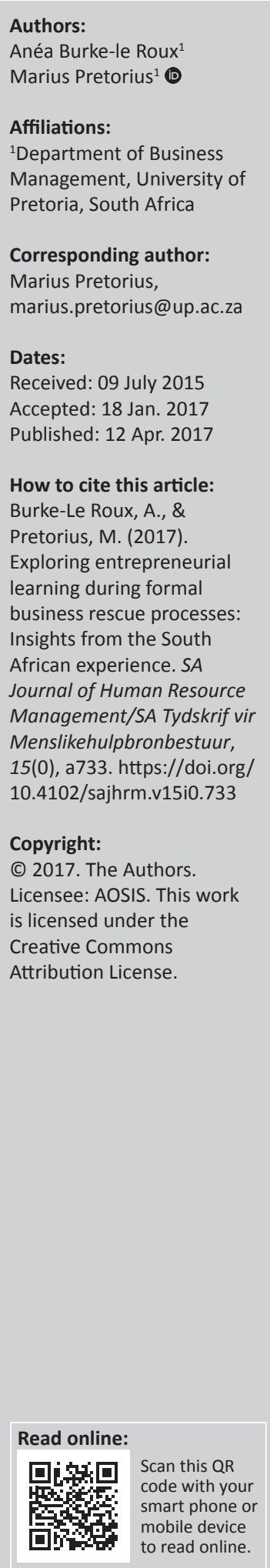

Orientation: Currently, little is known about entrepreneurial learning under turnaround and rescue conditions. A better understanding of the content dimensions as well as the factors that drive or restrain entrepreneurial learning during business rescue (BR) is relevant for theory and industry development.

Research purpose: BR is a fairly new regime in South Africa that extends beyond turnaround practices. It is acknowledged that business failure can fuel cognitive processes and subsequently entrepreneurial learning but to what extent in the context of formal BR proceedings requires exploration. Practice suggests that the role of the business rescue practitioner (BRP) as 'disproportionate influencer' can affect the learning of filing entrepreneurs.

Motivation for the study: In the absence of guidelines, this study set out to explore and make sense of the specific content dimensions that entrepreneurs learn during such proceedings to assist role players.

Research design, approach and method: The research question for this exploratory investigation obtained first-hand accounts from subjects that have been directly involved in BR proceedings. Semi-structured interviews were conducted. 'Investigator triangulation' was also used to extract as much richness and data as possible applying interpretative phenomenological analysis.

Findings: We extracted three key content dimensions which entrepreneurs learned during BR: rescue process, business related and personal learnings. Entrepreneurs with 'positive' experiences of BR learned more than those with negative experiences. The key driving and restraining factors to entrepreneurial learning were both associated with the behaviour of the BRP.

Practical/managerial implications: BR has introduced another dimension to learning from business failure. Understanding the content dimensions learned by entrepreneurs during BR broadens insights of the Regulator, BRPs and educators about the potential long-term effects of $\mathrm{BR}$ on the factors that can either drive or restrain learning during BR proceedings.

Originality and value: The findings led to an enriched understanding of specific entrepreneurial learning content dimensions that take place under BR proceedings. It also directs future research into entrepreneurial learning when effected by BR.

\section{Introduction}

Those that fail to learn from history, are doomed to repeat it. (Winston Churchill)

Following in the footsteps of developed economies such as the United States (US) (Chapter 11 of the Bankruptcy Code, 1978), the United Kingdom (UK) (Cork Committee, 1982), Canada and Australia, South Africa has through the introduction of the Companies Act (No. 71 of 2008) ('the Act') in April 2009 joined the international community in adopting a modern corporate reorganisation regime. The Act came into effect on 01 May 2011. Chapter 6 is aimed at addressing the need for a business recovery mechanism (Kloppers, 1999; Westbrook, 2010) that provides for 'the rescue and recovery' of businesses that are financially distressed, in a way 'that balances the rights and interests of all relevant stakeholders' (s7[k]) (Du Toit, 2012, p. 1). The institution of business rescue (BR) through Chapter 6 of the Act has introduced a new regime of reform for South African businesses facing insolvency by proposing BR as an alternative to liquidation. Despite the novel intentions and potential of the Act, it came with its own set of problems, to the extent that revision of the Act was formally started in 2016. 
It is important, at this junction, to qualify the business rescue practitioner (BRP) in relation to the turnaround professional (TP) associated with Chapter 11 as these terms are often used interchangeably. Under Chapter 11, the TP works with the debtor in possession (DIP) who is the management of the distressed firm. Together they produce a plan to lay before the court for ratification. Generally the process is regarded as an 'informal' process with the management remaining (DIP) in charge. Compare this to Chapter 6 where the BRP is appointed after 'formal' filing and once appointed are given sole decisionmaking powers until the plan is presented to the creditors for voting to support the plan, which must then be implemented by the BRP. Pretorius (2016) reports that the filing directors (often owners or shareholders) lose all powers in this relationship. BR therefore brings about a different boundary condition for potential learning of the entrepreneur (as well as management and shareholders) compared to turnaround.

With the rescue industry being just over 5 years old, it can be considered to still be in the process of overcoming its growth pains. A recent technical report by Pretorius (2015) highlighted some of the challenges associated with this 'new' recovery regime. One of the key findings of the study was that the BRP is a 'disproportionate influencer', as the BRP can be connected to everything that is happening in the process (Pretorius, 2015, p. 78). However, his report is silent on learning aspects. This highlighted the need for BRP-related tasks and issues such as the accreditation, regulation and competencies of the $\mathrm{BRP}$, to receive optimal attention to influence the outcomes of the process. With the BRP having such influence in the rescue process, it is important for the Regulator and affected parties to understand the practice events to make sense of the specific learning influences that a BRP may have on not only the process but specifically on entrepreneurs (often the filing director or directors or managers). In this study, we not only use entrepreneurial learning as umbrella term but also include small business directors who are often the entrepreneur, owner, shareholders and potentially all. All subjects in this study were entrepreneurial owners.

Could a turnaround or BR event be judged successful if no knowledge transfer took place during the process? Logic suggests that after BR, if successful, control of the business is given back to the entrepreneur as filing director. It may therefore be assumed that BRPs are expected to dispense knowledge to the entrepreneurs, as the entrepreneurs will retake management control of the business again after the substantial implementation of the BR plan. In a recent review, Walsh and Cunningham (2016, p. 249) highlighted the entrepreneurial learning issues that can take place during business failure and call for extending the research. Simultaneously, very little is known about what entrepreneurs learn under formal BR proceedings, which have the added dimension of the BRP as a 'disproportionate influencer'. Currently, the body of knowledge about practice events that encourage or restrain entrepreneurial learning during the BR process is limited. There is also no clarity on the specific content dimensions of the learnings that are gained by entrepreneurs under the new recovery regime.
Drawing on sense-making theory (Weick, 1995), the phenomenon of entrepreneurial learning during BR was explored by investigating specific episodes that were triggered by specific events, interpreted through specific processes to generate specific outcomes that are influenced by several situational factors (Sandberg \& Tsoukas, 2015). The study sets out to explore BR practice events that can drive or restrain entrepreneurial learning, as well as understand what some of the specific content dimensions are in this context. In-depth qualitative interviews were conducted to gain insights into practice events which can guide the process of making sense of the phenomena of entrepreneurial learning during BR.

\section{Purpose of the study}

Although it is acknowledged that business failure fuels several cognitive processes and subsequently entrepreneurial learning (Walsh \& Cunningham, 2016), not much is known about the phenomena of entrepreneurial learning under the newly instituted business recovery regime. While it may be expected that BRPs as 'disproportionate influencers' should share knowledge with the entrepreneurs as part of their tasks, little is known about practice events. This study thus sets out to make sense as a first episode by exploring the content dimensions that entrepreneurs, as owners or filing directors, learn during formal BR proceedings. Also, the factors that may restrain or drive entrepreneurial learning during BR proceedings are investigated.

The study has thus embarked on an area of BR that has not been studied previously, namely: to document entrepreneurs' personal accounts of learning during BR proceedings. It is also of particular interest at this juncture as Pretorius (2016) reported on the adverse relationships between BRPs and filing directors. While previous research has discussed broad content dimensions of what entrepreneurs learn from failure, this study hopes to extend with a 'better understanding', the learning effects during BR at an individual level as they are handed back the control of the business after substantial implementation of the rescue plan is filed by the BRP. If they have not learned from the process, the businesses are likely to experience the same distress in future colloquially referred to Chapter 22 in the United States and Chapter 12 in South Africa.

The investigation aims to inform future studies focussing on how the entrepreneurial learning during BR can be enhanced by making sense of the factors that entrepreneurs perceive to encourage or limit their learning during BR proceedings. Beyond that, this study is intended to assist the Regulator with insights into the factors needed to create an environment that is conducive to learning and bridge factors that restrain it; to equip BRPs with knowledge to help them promote entrepreneurial learning; and lastly to provide educators with lessons learned during BR proceedings, which can serve as directive for training programmes. We start with a literature review from which the research propositions were derived, followed by a description of the research design and methodology and lastly the findings and a discussion. 
For the purposes of this study, entrepreneurs, business owners and directors were considered the unit of observation, as the researchers acknowledge that entrepreneurial learning is not limited to entrepreneurs only, as per the definition of an entrepreneur suggested by Wickam (2000). The term 'entrepreneur' is used interchangeably with 'business owner' as well as 'filing director' for the purposes of this study.

\section{Literature review}

The process of formal BR is known to be a highly stressful process for the BRPs, directors, owners, as well as for other stakeholders and other 'affected persons'. Although business failure is recognised as being potentially painful and damaging to entrepreneurs (Cardon \& McGrath, 1999; Cope, 2011), previous studies clearly highlight that negative experiences, arguably such as business failure or rescue, can stimulate learning and adaptation processes (Shepherd, 2003). Cope (2011) has explored some of the content dimensions which entrepreneurs learn during business failure. Mismanagement is often quoted as a common cause for business becoming distressed and in need of BR (Pretorius \& Holtzhauzen, 2008). It is, therefore, vital to know what entrepreneurial learning takes place during BR proceedings to study the potential effects of $B R$ on individual entrepreneurs. As entrepreneurs play an important role in economic development and employment, the Regulator needs to understand whether entrepreneurs benefit in knowledge during an intervention such as BR, and what role BRPs play in such learning as 'disproportionate influencers'. Drawing on sense-making theory, this study aims to investigate some of the content dimensions that entrepreneurs learn during the stressful process of BR.

\section{Sense-making theory}

Following a disruption associated with one's environment (filing for BR) new sense making for improved understanding is required. Sense making is seen as a cognitive process. By interpreting information derived from the external environment and from internal learning, purposeful action is instigated and that leads to change (Gioia \& Chittipedi, 1991, p. 433). Weick (1995), who is seen as the father of the theory, characterises sense making by the following seven building blocks: (1) It is grounded in identity construction - thus who one is, determines what sense is made. (2) It is a retrospective process. (3) It is enactive of sensible environments - linked to what people do. (4) It involves social interaction, (5) on an ongoing basis - thus 'episodic' in nature, (6) focuses on and extracted by cues (signalling) and (7) driven by plausibility rather than accuracy.

While often used synonymously, understanding and interpretation are not equivalent to sense making (Weick, 1995, p. 14). Similarities might exist between the concepts, but there are several distinguishing factors that set sense making apart from understanding, as well as interpretation. Weick (1995) states that interpretation is a component of sense making but that, while interpretation is not irrelevant, sense making matters because a mistake in sense making could have dire consequences. The key distinction is that sense making is about the ways people generate what they interpret. It therefore refers to how people make sense of their experiences in the world (Klein, Moon \& Hoffman, 2006, p. 70), it is a process by which individuals develop cognitive maps of their environment (Ring \& Rands, 1989, p. 342) as referenced by Weick (1995, p. 5).

The applicability of the sense-making theory is twofold for this study. First, the subjects retrospectively state their own experiences when probed during interviews about learning content. Second, the researchers made sense of the data collected from the interviews and based on previous learning literature to propose an 'initial map' of the insights gained from the process.

\section{Challenges surrounding business rescue}

Following the institution of Chapter 6 of the amended Companies Act (71 of 2008), some studies have started exploring the challenges and phenomena around the new business recovery model for the Regulator and stakeholders to gain insights to influence future outcomes.

BRPs are central to all the activities that takes place from their appointment, which takes place within 5 days after the rescue filing process, until substantial implementation of the plan is reached, thus making them 'disproportionate influencers' (Pretorius, 2015, p. 78). Pretorius and Holtzhauzen (2008) conducted research on the key liabilities that BRPs are faced with and highlighted the fact that BRPs face a task of immense proportions. Legitimacy, resource scarcity, leadership capacity, strategy options, data integrity and integration were found to be the most relevant liabilities that BRPs had to address. The liability of strategy options is a key liability as a turnaround strategy will only be truly effective in reversing decline if it addresses the declining firm's core problem (Barker \& Duhaime, 1997). As the origin of the causes of failure is categorised as either strategic or operational in nature (Robbins \& Pearce, 1992), operational preconditions can be corrected with relative ease and expectation of success, while strategic preconditions require directional change and highrisk expectations (Pretorius \& Holtzhauzen, 2008). Data integrity and integration can also be a significant liability for a BRP, as data often mark and mask the core problems rather than being of assistance (Pretorius \& Holtzhauzen, 2013). Expert BRPs, however, develop what could be termed 'verifier determinants' of early warning signs, to enhance their decision-making (Pretorius \& Holtzhauzen, 2013). Verifier determinants can be classified into five categories: management, finance, strategic, banking and operations and marketing of the ventures under investigation.

Le Roux and Duncan (2013) expanded on the work of Pretorius and Holtzhauzen (2008) by noting that each liability which BRPs have to address is accompanied by equal concerns from a creditor point of view. A major concern from the creditors' perspective is that they are not always informed 
timeously about a company's BR status, and effective communication is therefore vital when commencing BR (Le Roux \& Duncan, 2013). Their study found that unsecured creditors often had little to no knowledge of the Act, which also left creditors with unanswered questions and concerns. Effective communication during rescue proceedings is a statutory requirement to adequately inform creditors. Creditor communication primarily takes place in the form of creditors' meetings and notices. In the examination of the reorganisation plans of four prominent regimes, Pretorius and Rosslyn-Smith (2015) found that the plan serves as a tool for feasibility declaration, a medium of communication, an enabler of transparency, a contractual obligation and finally to assist decision-making for attracting post-commencement finance.

These studies have given insights into BR from a creditor and BRP perspective. Yet the existing body of knowledge on the experience of individual filing directors as entrepreneurs during BR remains largely understudied. This is even more so true with regard to what is known about the practice events under which entrepreneurial learning takes place as well as specific learning content dimensions that are gained during proceedings. It leaves a gap in the Regulator's, BRPs' and educators' understanding of the longevity of BR if entrepreneurial learning is impeached.

\section{Business failure}

Over the past decade, there has been an increase in literature that sets out to define, clarify and better understand business failure. While each company's life cycle can differ in terms of its ultimate level of failure, distress or success, no organisation is exempt from experiencing certain degrees of highs and lows throughout its life cycle (Burbank, 2005). Failure should not be narrowly conceived as only being bankruptcy and liquidation, as failure may also involve the loss of capital and not being able to continue a business on a profitable basis (Cochran, 1981). Shepherd, Douglas and Shanley (2000) also stressed the failure red flags of unexpected declines in revenue and/or increases in expenses which may imply that the business cannot continue under its current management or ownership. A distinction can be made between decline and failure. Failure marks the endpoint of the success-failure continuum, and when this discontinuance (bankruptcy) is reached, operations cease and judicial proceedings come into effect. The process leading up to this can be defined as decline and distress (Pretorius, 2009). In the context of the Act, a company is perceived as being distressed and is eligible to file for BR when it is unlikely to pay all its debtors in the ensuing 6 months.

\section{Costs of failure}

Business failure can influence entrepreneurs in a number of ways, both positive and negative. In his study on better understanding entrepreneurial learning from failure, Cope (2011) identified six distinctive spheres in which failure influences entrepreneurs, namely: financial, emotional, physiological, social, professional and entrepreneurial.
The study found that all of the participants experienced some sort of financial loss, but most participants highlighted that the emotional cost was far more difficult to deal with. Similarly, Shepherd, Wicklund and Haynie (2007) acknowledged that failure is financially costly to entrepreneurs but found that emotional costs dominate over financial costs. The findings further indicated that the emotional impact of failure is linked to its social cost (Cope, 2011). The social cost referring to the way entrepreneurs fear others will respond to their failure as well as their personal sense of failure as they are not able to deliver to investors, employees, creditors and family. Failure did seem to have a negative impact on entrepreneurial self-efficacy and risktaking propensity (Cope, 2011). Similarly, it can be argued that entrepreneurs whose businesses are in formal BR are faced with added emotional costs, as the BRP takes control of the business once a majority vote in favour of the rescue plan has been obtained. It is not clear how this added dimension affects the entrepreneurial learning that takes place in the context of formal BR proceedings. Practical experience suggests that when firms are distressed, the 'good' employees leave first for alternative employment leaving behind those who cannot find such alternative employment. This emphasises the crucial relationship with human resource management by both the BRP during BR and the entrepreneur as management before and after BR.

\section{Learning from failure}

Making sense of the phenomenon of learning from business failure conditions can add to what we know about how entrepreneurs learn and respond to failure (Huovinen \& Tihula, 2007), thus learning from failure is relevant for all management. This is even more true in the South African BR context, where very little is known about entrepreneurial learning that takes place during proceedings. Using quasifield experiments and laboratory tests, Ellis, Mendel and Nir (2006, p. 670) have found that failures are the 'fuel that intensifies cognitive processes'. Although failure can be both painful and damaging to entrepreneurs, Cardon and McGrath (1999) and Shepherd (2003) have theorised about the learning and knowledge that entrepreneurs can gain from such situations. There are two dominant views on learning from negative experiences such as business failure (Pretorius \& Le Roux, 2011). Barker and Moné (1998) argue that organisational decline constrains cognitive processes, limits decision-making and restricts the available options. Their approach is limiting to organisational change and/or adaptation and may result in threat-rigidity theory (Pretorius \& Le Roux, 2011). On the other hand, Shepherd (2003, p. 318) postulated, 'negative emotions stimulate search processes, learning, and adaptation'.

Politis (2008) used experiential learning theory as guiding framework and identified two critical career experiences that can be associated with more positive attitudes to failure, namely the prior start-up experience and the business closure experience. Both these experiences are valuable in the development of an entrepreneurial mindset, in which failures can be seen as opportunities for learning (Politis \& Gabrielsson, 2009). 
Using the literature on grief and related emotions, Shepherd (2003) attempted to gain deeper insights into how the selfemployed learns from business failure. Shepherd (2003) found that the self-employed learn from business failure when they can make use of the available information on reasons why the business failed, namely feedback information, to revise their current knowledge about how to successfully manage a business (Shepherd, 2003). This learning can help them to revise their assumptions regarding the consequences of previous decisions, action and inaction. The approach described by Shepherd (2003) of how the self-employed learn from business failure in the process of grief shows a very strong relationship with the action learning approach as described by McGill and Beaty (2001) and Watson (2004). They describe action learning as a process that includes action, deliberate reflection, generalisation and testing. Hence, an action learning approach may be very effective to promote learning from failure and can form part of the grief recovery process. By employing an action learning approach, entrepreneurs can stop and reflect on their actions and current situation, and in so doing ultimately change their future behaviour as a result.

We proposition in this study that during BR proceedings, the BRP 'moderates' the entrepreneurial learning conditions to such an extent that learning may be impaired. We want to better understand if learning takes place and if so, what is learned or if not, why not. We take cognisance of Pretorius (2015) report to the Companies and Intellectual Property Commission (CIPC) that states the 'disproportionate influence' on the process by the BRP.

\section{The content dimensions of learning from failure}

Although previous studies paid attention to the process of learning from business failure (Shepherd, 2003; Shepherd et al., 2007), there still remains fairly scant evidence of the specific content dimensions of such entrepreneurial learning and specific 'learning tasks' associated with business failure (Cope, 2005a, p. 380). Cope (2011) conducted an interpretive phenomenological analysis with eight entrepreneurs who experienced business failure, to highlight the distinctive learning tasks that can be achieved by higher level learning in a business failure situation.

Learning outcomes from failure can be placed in four broad themes, namely: learning about oneself, the business (and its demise), networks/relationships and business management (Cope, 2011). Table 1 expands these outcomes.

Although past literature clearly indicates that failure can provide valuable learning opportunities for entrepreneurs, there seems to be a lack of research on entrepreneur's experiences (Blackburn \& Kovalainen, 2008; Cope, 2011). Cope's interpretive phenomenological analysis study with eight entrepreneurs (2011) highlighted four broad failure learning content themes. There still remains a need to better understand entrepreneurs' experiences of failure as well as what and how they learn from failure. Because of the newness of the Act, there is specifically a need to understand entrepreneurs' learning experiences and the specific practice events around such learning. Insights into the specific learning content dimensions as well as driving and restraining factors can create a cognisance to guide the Regulator and BRPs in their approaches to rescue proceedings.

\section{Method}

\section{Research objectives and questions}

Past studies have demonstrated that entrepreneurs can learn from their personal critical business experiences of failure. Table 1 highlights four broad content dimensions that entrepreneurs learn during failure. This study sets out to address the gap in research on entrepreneurs' personal accounts of learning from business failure in a South African BR context by interviewing entrepreneurs who have entered and experienced BR proceedings. Therefore, the following investigative questions guided the research:

- What are the specific content dimensions that entrepreneurs learn during BR proceedings?

- What are the factors that drive entrepreneurial learning during BR proceedings?

- What are the factors that restrain entrepreneurial learning during BR proceedings?

\section{Research design and methodology}

\section{Research approach}

The research approach was exploratory and qualitative in nature. We set out to better understand, identify and explain the embedded learnings and experiences of entrepreneurs whose businesses have undergone formal BR proceedings. The fact that local literature focussing on BR from an entrepreneur's, owner's or director's perspective is limited suggested that a qualitative research approach could be used to explore this understudied phenomenon in more detail (Cooper \& Schindler, 2008). Hence, this study did not attempt to gather data for generalisation purposes but rather focused on providing an exploratory description of the content dimensions of learning during BR proceedings

TABLE 1: The entrepreneurial learning task outcomes of failure.

\begin{tabular}{ll}
\hline Learning task dimension & Learning outcomes described \\
\hline Oneself (personal) & $\begin{array}{l}\text { This involves learning about one's strengths, } \\
\text { weaknesses, skills, attitudes, beliefs and areas for } \\
\text { development. It is stimulated by 'transformative } \\
\text { thinking'. }\end{array}$ \\
The business (and its demise) & $\begin{array}{l}\text { The entrepreneur learns about the strengths and } \\
\text { weaknesses of the business, including the reasons } \\
\text { for failure. This learning task dimension is stimulated } \\
\text { by 'double-loop learning'. }\end{array}$ \\
Networks and relationships & $\begin{array}{l}\text { Importantly, this learning task dimension is centred } \\
\text { on learning about the nature and management of } \\
\text { relationships, both internal and external to the } \\
\text { business. It is stimulated by transformative and } \\
\text { double-loop learning. }\end{array}$ \\
Business management & $\begin{array}{l}\text { Business management as a learning task dimension } \\
\text { is about learning how to run and control businesses } \\
\text { more effectively in relation to the wider } \\
\text { environment. It can be stimulated by 'generative } \\
\text { learning'. }\end{array}$ \\
\hline Source: Adapted from Cope (2005a, p. 380) and Cope (2011, p. 616)
\end{tabular}


TABLE 2: Research design components.

\begin{tabular}{ll}
\hline Component & Description \\
\hline Research problem & There is no clarity of what entrepreneurs learn under \\
formal business rescue proceedings and how such \\
learning can be promoted or hampered.
\end{tabular}

Source: Modified from Yin, R.K. (2003). Case study research: Design and methods. Thousand Oaks, CA: Sage, p. 21

$\dagger$, The propositions were set to structure the research process and support the research questions.

(see Table 2), as well as the factors that can drive or restrain such learning.

\section{Key scientific beliefs of the researchers}

In order to answer the previously mentioned questions, the researchers were aware of their own philosophical assumptions and methodological values. Both researchers are objective realists who believe that knowledge is generated from facts associated with real-life cases and their contexts. Where either researcher found repeated mentions of causes, practices and responses, they could 'generalise' them. The researchers aimed to maintain a critical view of all the data reviewed and interpret it in the framework of existing literature on BR and entrepreneurial learning from business failure, while also allowing for the data to 'speak for itself' because of the newness of the BR phenomenon.

\section{Research setting and background}

Eight interviews were conducted with entrepreneurs, business owners and directors whose businesses have undergone BR proceedings as a result of voluntary filing. Subjects were purposively selected and were not selected to represent certain
TABLE 3: Interview statistics.

\begin{tabular}{ll}
\hline Description & Quantity \\
\hline Total number of interviews & 8 \\
\hline Total length of all interviews & 493.22 minutes \\
Average length of interviews & 61.65 minutes \\
Shortest interview & 41.23 minutes \\
Longest interview & 81.11 minutes \\
\hline
\end{tabular}

industries or business size. All subjects that have been interviewed have filed for BR in 2012 or 2013. A semi-structured interview format was utilised. Follow-up non-standardised telephonic and one-on-one interviews with subjects were also conducted to extract the maximum information out of subjects as they shared their experiences (Saunders, Lewis \& Thornhill, 2009). Both open and closed questions were employed to improve the researchers' understanding of the results (Cooper \& Schindler, 2008). During the interview, subjects were requested to reflect on their personal experience of BR proceedings. Following a brief open-ended discussion, the subjects were guided with a protocol to help them recall the events that took place during the BR proceedings chronologically and then paused to reflect on possible learnings at key intervals during the BR proceedings. In conclusion, subjects were requested to summarise their key learnings as well as possible factors that enabled or prevented them from learning, to cross-reference this with the information that has been provided earlier in the interview.

\section{Sampling}

The research question required first-hand accounts from subjects that have been directly involved in rescue proceeding. Hence, the target population of this study was entrepreneurs, business owners and directors whose businesses have undergone BR proceedings in South Africa as a result of a voluntary filing. The sample was thus not selected to be representative of a certain community, for example, sector or business size, but rather to provide much needed insights into the phenomenon of learning under rescue proceedings. Because of the limited data available on businesses that have filed for BR as well as the specific criteria for subjects, namely voluntary filing for BR, a purposive snowball sampling strategy was used. The researchers tapped into their academic and business networks and also utilised referrals to qualify potential subjects. Similar to Cope's (2011) interpretive phenomenological analysis to determine the distinctive learning tasks that can be achieved by business failure, this research followed suit. The sample size for the research was determined after theoretical saturation arose. Eight interviews sufficed for this purpose, as theoretical saturation was reached at that point (Table 3). This is supported by the work of Guest, Bunce and Johnson (2006, p. 78) which suggests that 'a sample of six interviews may be sufficient to enable development of meaningful themes and useful interpretations'.

\section{Data analysis}

As the study was exploratory and qualitative in nature, an interpretative phenomenological analysis was used to analyse the data. A phenomenological analysis allows for 
deeper levels of insight into the entrepreneur's experiences, which can be applied for theory building purposes.

The phenomena that the researchers investigated included the subjects' perspectives, thinking, experiences and perceptions of situations. Table 4 gives a clear outline of the levels of interpretative phenomenological analysis that was applied during the data analysis.

\section{Strategies used to ensure data quality}

Although there was only one key source of evidence, namely the entrepreneurs, 'investigator triangulation' was used to extract as much richness and data as possible (Yin, 2003, p. 98). During interviews, we ensured that subjects were relaxed and could exit at any time to address potential subject fatigue. The entrepreneurs all were happy to share their experiences voluntarily. The subjects were telephoned several times to confirm the interpretations of the researchers. As sense making was the objective, we wanted the subjects to voice their own experiences as well as their learnings from the experience.

Quality was also pursued through repeated views of the data transcriptions, specifically those of the entrepreneur's own version of their experiences, each evaluation, interview notes, and also by checking the researcher interpretations. We were open to all possible themes as we wanted to make sense of the individual experiences. The developed themes were informed by the content dimensions (see also Table 4) on entrepreneurial learning (Cope, 2005a, 2011). We enhanced the content dimensions by adding positive affect (driving) and negative affect (restraining) as factors. One researcher also interrogated the interpretations applying devil's advocacy. Finally, we used verbatim quotes in the discussion to convey the personalised learnings of the subjects.

We proceed by stating the findings as the research progressed followed by the discussion in search of improved understanding. Finally, we highlight contributions and potential consequences while acknowledging the limitation and proposals for future research.

\section{Findings}

Figure 1 introduces a framework based on the findings of the research. The middle column indicates content dimensions of 'what' entrepreneurs reported as learnings during BR proceedings. The learning content dimensions can be grouped into three broad categories, namely learning about the process, learning about the business as well as personal learnings. Arrows pointing into this middle column shows the origin of the specific learnings to be either from subjects with a positive $\mathrm{BR}$ experience or those with a negative experience.

The column to the left lists the driving factors, which enabled or helped create an environment that is conducive to entrepreneurial learning in a BR context. The third column highlights the factors that restrained the entrepreneurs from learning under BR proceedings. It is important to note that 'positive' or 'negative' experiences from BR was not defined by whether the business went into liquidation, discontinued operations or continued operations after rescue but is rather based on 'how' the entrepreneur described their experience of BR, regardless of the continued existence of BR. Important to notice is that the BRP effected both positive and negative experiences and both drivers and hindrances.

TABLE 4: Levels of interpretative phenomenological analysis used to extract insights from subjects.

\begin{tabular}{|c|c|c|}
\hline Process of analysis & Level of analysis & Description of analysis \\
\hline Gaining insight into data & Reading the case data & $\begin{array}{l}\text { This involved the reading and re-reading of a transcribed interview to gain an understanding of the complete story and } \\
\text { recall the interview, and also to become 'close' with the story by doing so (Senior, Smith, Michie \& Marteau, 2002). } \\
\text { Memos were taken to capture insights that arose on the issues that were identified (Patton, 1990). }\end{array}$ \\
\hline Sense-making & Diagnosis of the case & $\begin{array}{l}\text { Throughout the process of sense-making, a 'free textual analysis' (Smith \& Osborn, 2008) was conducted. Potentially } \\
\text { important quotes were highlighted. Based on Hycner's (1985) practice, 'units of meaning' were identified within each } \\
\text { of the transcripts. The units, for example, 'personal learning', were then grouped to form common clusters of } \\
\text { meaning. Each cluster was colour coded throughout the transcripts. }\end{array}$ \\
\hline Categorisation & $\begin{array}{l}\text { Developing 'intra-case } \\
\text { themes' }\end{array}$ & $\begin{array}{l}\text { By linking the insights gained by reading the data with the highlighted clusters within each transcript (previous two } \\
\text { stages), emerging themes could be noted within each transcript. The process of identifying 'clusters of meaning' } \\
\text { resulted in a 'master-theme list' (Smith, Jarman \& Osborn, 1999) for each of the transcripts. }\end{array}$ \\
\hline $\begin{array}{l}\text { Association/ } \\
\text { re-categorisation }\end{array}$ & $\begin{array}{l}\text { Developing 'inter-case } \\
\text { themes' }\end{array}$ & $\begin{array}{l}\text { After this, a comprehensive analysis was conducted across all the transcripts. The individual 'master-theme lists' were } \\
\text { then compared, main categories grouped together and merged to form a single 'master-theme list'. The final single } \\
\text { 'master-theme list' illustrated the connections between the transcripts (Easterby-Smith, Thorpe \& Lowe, 2002). During } \\
\text { this step, overlaps in experiences were recognised which allowed for identifying categories of similar themes across all } \\
\text { the accounts (Smith et al., 1999). General and unique themes in the transcripts were identified in the single } \\
\text { aggregated 'master-theme list' (Hycner, 1985). }\end{array}$ \\
\hline
\end{tabular}

Re-reading accounts Coding After compiling the single aggregated 'master-theme list', all transcripts were read again, and previously identified themes were coded in accordance with the new 'master-theme list' to ensure clarity and consistency when documenting the findings in the next step.

Interpretation/ Writing up

Techniques that focus on discovery seeks to identify patterns between sections of data and require inductive reasoning to be applied (Fossey, Harvey, McDermott \& Davidson, 2002; Leedy \& Ormrod, 2001).

During the stage of formally writing up the findings, there was an interaction between 'the interplay between the interpretative activity of the researcher and the participant's account of her experience in her own words' (Smith \& Eatough, 2006, p. 338). Despite the emphasis having been on describing the shared experiences of the entrepreneurs, this stage still voiced some entrepreneur's individual experiences (Smith et al., 1999). In order to maintain a phenomenological, inductive approach to theory development, the findings were written directly from the transcribed data, without employing of any relevant academic literature. By doing so, the data were allowed to 'speak for itself' (Cope, 2005b).

Explanation Consulting literature

This stage involved consulting literature to produce theoretical explanations and achieve a higher level of abstraction (Eisenhardt, 1989). Thus, the research was phenomenologically grounded but was also hermeneutic and interpretative in nature (Berglund, 2007; Seymour, 2006). This stage included a comparative process of referring between existing theory, although rather limited, and the data (Yanow, 2004).

Source: Based on Cope, J. (2011). Entrepreneurial learning from failure: An interpretative phenomenological analysis. Journal of Business Venturing, 26(6), 611. https://doi.org/10.1016/j. jbusvent.2010.06.002 


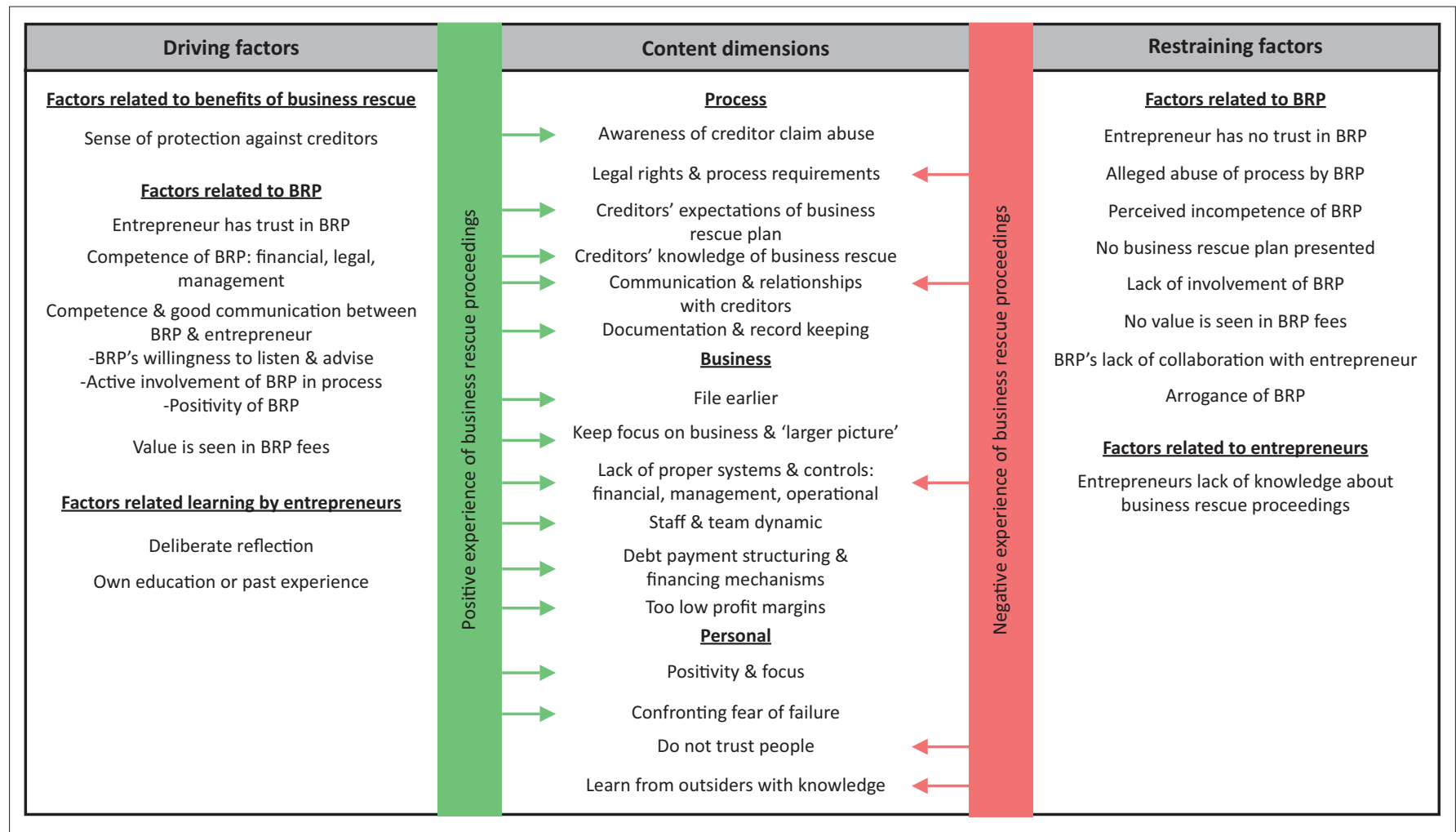

BRP, business rescue practitioner.

FIGURE 1: Conceptual framework of entrepreneurial learning from business rescue proceedings in South Africa.

Figures 2-4 expand the three learning content findings to explore the data collected associated with the middle column of Figure 1.

The process-related content included six dimensions of which five were identified by subjects with positive experiences, one by subjects with negative experiences and one dimension by both. Four of the dimensions have to do with 'creditor' effects and are explored in the discussion section. Because of the newness of the Act, most of the entrepreneurs (six of the eight subjects) in this study appeared completely unfamiliar with the concept of BR before they started searching for solutions to save their distressed businesses.

The business-related content included six dimensions of which all were identified by subjects with positive experiences and one dimension by both.

The personal learning-related content included four dimensions of which two were identified by subjects with positive experiences and two by subjects with negative experiences. Subjects reported a notable difference in the amount of learning that took place amongst the entrepreneurs who reported a positive experience of BR when compared to those who reported a negative experience of BR. The entrepreneurs who had a positive experience of BR had a combined total of 12 unique content leanings, whereas those with a negative experience had only 5 combined unique learnings. Further to this, there was also a remarkable difference in the actual learning content between these two categories of entrepreneurs.

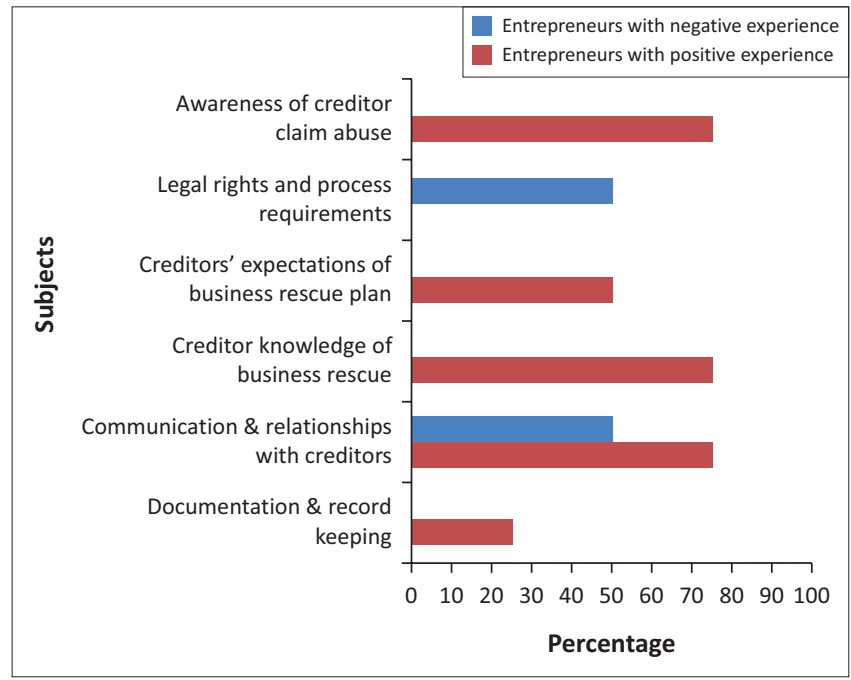

FIGURE 2: Relative indication (percentage reported) of process-related learning content dimensions identified by subjects.

We proceed by extensive discussion of the content-related findings related to process (Figure 2), the business learnings (Figure 3) and personal learnings (Figure 4). Where possible and length permitting, direct quotes were included to inform the discussion.

\section{Discussion of the findings}

The research uncovered several interesting additions in terms of entrepreneurial learning content dimensions (Cope, 2011) when a business is exposed to the rescue context. Most revealing, however, were the factors (see also Figure 1) that 


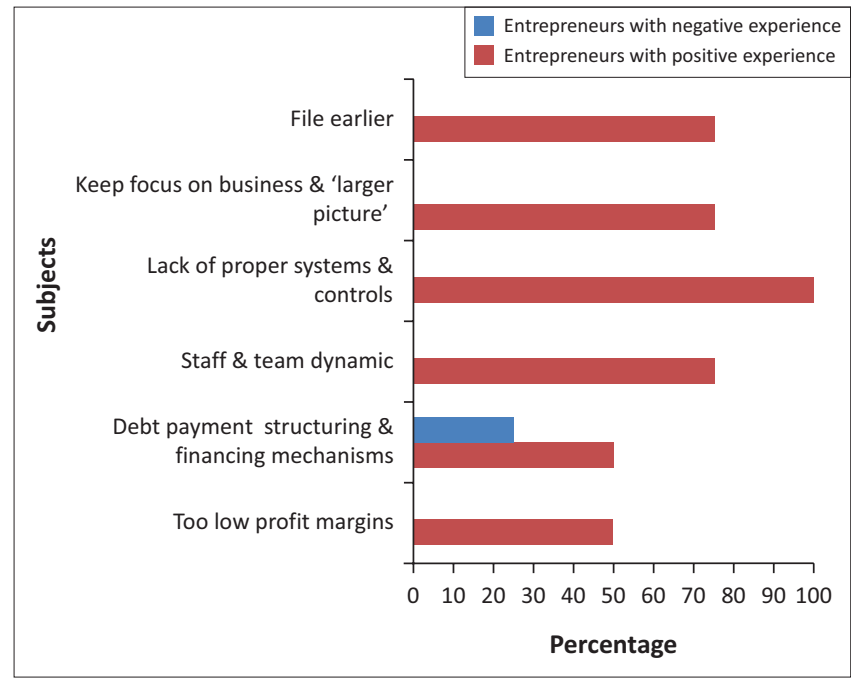

FIGURE 3: Relative indication of business-related learning content dimensions identified by subjects.

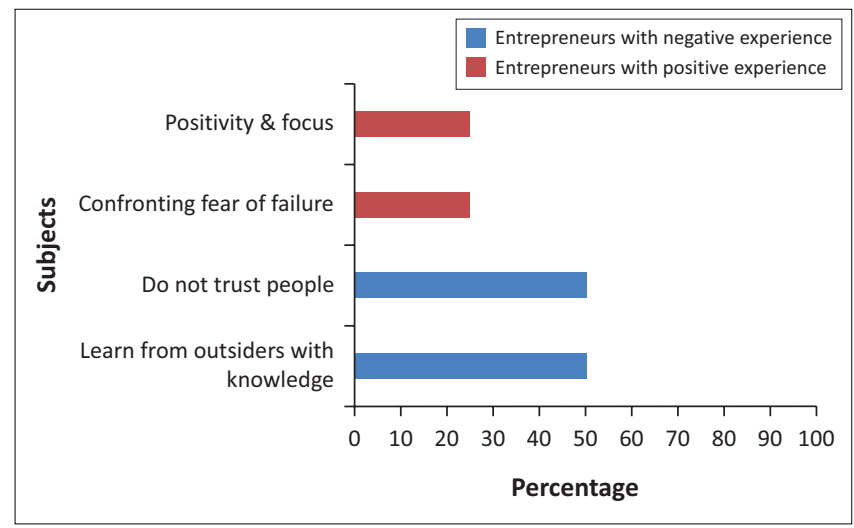

FIGURE 4: Relative indication of personal learning content dimensions identified by subjects.

are perceived to either limit entrepreneurial learning during BR proceedings or create an environment that will encourage such learning. Furthermore, the research indicated how the 'level' of learning or learning content dimension is influenced by whether the entrepreneur had either a positive or a negative experience of BR.

\section{Three content dimensions during business rescue}

The findings showed similarities with Cope's (2011) findings on the content dimensions of learning from failure, namely: learning about oneself, the business (and its demise), networks or relationships as well as business management. The learning content dimensions of entrepreneurs during BR proceedings can be placed in three broad categories, namely: learning about the BR process, learning about the business and learning about oneself or personal learning.

\section{Process learnings}

The first category of learning content dimensions is learning about the BR process. Even though some of the entrepreneurs ( 2 from 8 ) in the study were vaguely familiar with the concept of turnaround, it was their first time being involved in BR proceedings. This confirmed Le Roux and Duncan's (2013) findings on the knowledge absence of entrepreneurs about $\mathrm{BR}$, as potential creditors in their study. As it was their first real-life encounter with $\mathrm{BR}$ and because all the entrepreneurs had to adhere to the legal requirements of BR, some form of learning with regard to the process was to be expected. Most of the learning related to the process took place amongst entrepreneurs who had a positive experience of BR. Learning about creditors formed a common theme in process-related learnings. The category with a positive experience learned to be cautious of claim-related abuse by creditors, recognise the creditor's expectations of the BR plan and came to understand their level of knowledge on BR. Both categories of entrepreneurs became aware of the importance of consistent communication with creditors. In addition to learning about creditor communication, those with a negative experience only learned about the legal aspects of the process.

The main lesson that was taken by the individuals who had a positive experience was to become more cautious of creditors who can potentially abuse the opportunity presented to them by $\mathrm{BR}$ to raise their claims, by claiming for products or services that were never transacted to the business. These claims also shed light on a business-related area in which entrepreneurs learned to pay more attention, namely their financial systems and controls. As these systems were often not in place or up to date, it made it very difficult for entrepreneurs to know or confirm whether creditor claims were legitimate or not.

Furthermore, the entrepreneurs who had a positive experience learned about the knowledge of different types of creditors on BR, whereas the entrepreneurs with a negative experience did not learn anything with regard to this. The entrepreneurs learned about which type of creditors they perceived to be generally informed about BR, such as banks and revenue services, as well as the creditors that are generally not well informed, namely small and mediumsized enterprises (SME's) (mainly suppliers) and local municipalities. Although these learnings may be unique to each entrepreneur's experience and will not necessarily be the same in every BR, it gave them an idea of which creditors they should educate more or communicate better to, should they ever be involved in BR proceedings in the future.

Some of the entrepreneurs from the group who had a positive experience gained knowledge on creditors' expectations of the business plan. One entrepreneur stated that 'the plan should only include the most relevant information', as the entrepreneur found creditor's main concerns to be whether they are going to receive their money and when they will receive it. Another entrepreneur learned that creditors, especially the banks, are concerned whether the management team can be trusted. The learnings related to the expectations of the business plan echoes the findings of Pretorius and Rosslyn-Smith (2015) who examined expectations of the reorganisation plans of four prominent regimes. 
They reported that the plan was found to serve as a tool for feasibility declaration, a medium of communication, an enabler of transparency, a contractual obligation and finally to assist decision-making for attracting post-commencement finances.

The single process-related learning that was most intensely underlined by the entrepreneurs was the importance of effectively communicating with creditors and using existing relationships with creditors to avoid hostility. This finding correlates with a key entrepreneurial learning task outcome of failure that was identified by Cope (2011), namely learning about the nature and management of relationships. Most of the entrepreneurs felt that better communication with creditors could have saved them a lot of difficulty, as it was believed that the hostility of some creditors against BR was grounded in a lack of knowledge with regard to what BR actually entails. Entrepreneurs, who either used their relationships with creditors to gain their trust or effectively communicated with their creditors, hardly faced any creditor hostility. Instead, they were supported and encouraged by their creditors. Two entrepreneurs who had a negative experience of BR felt that by being personally involved in communicating with creditors, and not having the BRP do all the work, would have had a better effect on creditor's reaction to BR. Pretorius and Rosslyn-Smith (2015) acknowledge that a key success factor in the effective communication of a rescue plan is pre-engagement with affected parties, as this allows the BRP to manage expectations and educate stakeholders.

One entrepreneur learned to keep record of all communication during BR, to have all the necessary evidence, should the entrepreneur have to go to court to oppose a perceived 'unlawful liquidation'. The process-related learning that was limited to only entrepreneurs who had a negative experience of BR was learning about legal options as well as process requirements. Although all the subjects can be expected to know more about the legal aspects after BR than before, seeing that it was their first real-world experience of BR and that they had little to no former knowledge about BR, the group who had a positive experience of BR did not mention learnings about the Act as noteworthy lessons. This could be because the legal and process aspects were mostly left to the $\mathrm{BRP}$ in the latter case, whereas entrepreneurs focussed on other aspects of the process as well as their businesses.

Figure 2 shows that some of the entrepreneurs with a negative experience of BR did not learn much about the previously mentioned process-related content dimensions. This may be associated with the restraining factors to learning during BR that are discussed in this article.

\section{Business learnings}

The second type of learning that took place during BR proceedings involves learning related to the business. This learning content dimension echoes Cope's (2011) findings about entrepreneurial learning from failure. He found that the entrepreneur learns about the business and its demise as well as about business management (Cope, 2011). Learning related to the business itself include learning about the strengths and weaknesses of the business as well as the reasons for its failure, whereas business management as a learning task relates to how to run and control businesses more effectively in relation to the wider environment (Cope, 2011). It is interesting to note that the entrepreneurs who had a negative experience of BR only learned one specific business-related lesson, namely debt payment strategies and financing mechanisms, as indicated in Figure 3. Such limited learnings highlight the negative long-term influence that restraining factors can have on entrepreneurs who experienced BR, as it hardly encourages them to behave proactively but rather reactively in future circumstances by obtaining funding or changing debt payment terms, instead of looking to avoid the need for this.

A refreshing learning amongst the group who had a positive experience was that they learned to identify the early warning signs in a business and take action quicker like filing for BR much earlier. They felt that this could avoid much of the damage to the business as well as their business' reputation that took place during that time and could have significantly increased their business' chances of survival. Pretorius and Holtzhauzen (2013) reported that expert BRPs develop what could be termed 'verifier determinants' of early warning signs, to enhance their decision-making. Verifier determinants specifically address BRP liabilities of data integrity and integration. Verifier determinants can be classified into five categories namely, management, finance, strategic, banking and operations and marketing of the ventures under investigation (Pretorius \& Holtzhauzen, 2013). The significance of this finding lies not only in the fact that the entrepreneurs learned to identify earlier warning signs in their businesses, but also in the possibility that the BRPs managed to create a 'climate' that was favourable for such learning or knowledge transfer to the entrepreneur to take place.

Remaining focussed on the business and 'the larger picture' during the troublesome business decline and failure period seemed to be a key learning for most of the entrepreneurs who had positive experience of BR. Some entrepreneurs reported that BR proceedings have given them the opportunity to reflect on their businesses and start executing the basic business activities correctly, such as implementing and executing proper systems and controls. These entrepreneurs could thus reflect and identify their businesses' core problems. The origin of the causes of failure can be categorised as either strategic, which require directional change and high-risk expectations, or operational, which can be corrected with relative ease and expectation of success in nature (Pretorius, 2008; Robbins \& Pearce, 1992). Whether the core problems were operational in nature, such as the execution of proper systems and controls, or whether it is strategic in nature, these entrepreneurs were able to identify some of the key challenges in the business by employing an action learning approach, as described by Shepherd (2003). As strategy options are one of the key liabilities that BRPs are 
faced with (Pretorius \& Holtzhauzen, 2008), it can be argued that the entrepreneurs who could reflect on operational core problems were able to do so because of the pressure that the BRP removed by dealing with the strategic options while taking control over the affairs of the business.

The most prominent business-related learning of entrepreneurs who had a positive experience of BR was the realisation their businesses lacked adequate operational, managerial and, most importantly, financial controls. A lack of financial systems and controls appeared to be the greatest challenge that entrepreneurs identified. This ranged from inadequate bookkeeping systems, no forecasts, budgeting and spending controls, absence of cash flow projections, no tax return submissions and also a lack of knowledge on how to steer the business based on accounting reports. In conjunction with this, too low profit margins were also identified as a 'cause' for some of the problems that were faced. Some entrepreneurs learned that during this turbulent time in the business, proper management controls were often neglected because the managers focussed their attention in other areas of the business as the problems in the business mounted. It was felt that by reintroducing discipline into the business and by managing teams more closely, problems such as a lack of maintenance, shrinkage as well as low productivity could be overcome. This finding is in alignment with Argenti's (1976) seminal report on contributors to failure, as well as the verifier determinants of early warning signs, including management, finance, banking and operations, which expert BRPs use in their decision-making (Pretorius \& Holtzhauzen, 2013). It indicated that the entrepreneurs with these learnings were able to reflect during BR on some of the potential 'causes' of their businesses' failure.

Amongst the entrepreneurs who had a positive experience of BR proceedings, some stated that it presented them with the breathing space needed to focus on their staff morale and team dynamic, which ultimately resulted in better customer service and productivity. This learning echoes the entrepreneurial learning task of learning about the nature and management of relationships (Cope, 2011), whereas subjects learned to promote staff morale during the BR process. Another lesson pertaining to staff that some entrepreneurs reported was to employ the correct staff for the correct positions from the start, even if it costs more or means employing fewer staff. One entrepreneur found that by replacing a department of three staff members by two more effective and experienced staff members, who collectively earned what the previous three staff members collectively earned, resulted in much higher productivity and outputs.

Both categories of entrepreneurs who had a positive and negative experience of BR learned how debt payment structuring, as well as financing mechanisms, can help improve cash flow in their businesses, as shown in Figure 3. A key difference that was observed between these categories is that entrepreneurs who had a positive experience of BR learned a number of other business-related lessons, whereas this was the only business learning for the entrepreneurs who had a negative experience of BR.

\section{Personal learnings}

This content dimension is aligned to Cope's (2011) findings of entrepreneurial learning tasks from failure, namely learning about oneself. It involves learning about one's strengths, weaknesses, skills, attitudes, beliefs, and potential development areas. When compared to the amount of business and process-related learnings, subjects reported the least personal learnings. As personal learning is closely associated with the entrepreneurs' personal experience of BR, there is a very clear difference between the personal lessons learned by entrepreneurs who had a positive experience of $\mathrm{BR}$ and those who had a negative experience.

Some of the entrepreneurs with a negative experience of BR learned that they should not blindly trust other people in the business environment. Furthermore, they felt that they would have been more equipped to navigate through BR if they surrounded themselves with people who have knowledge on BR. In contrast to this, one entrepreneur who had a positive experience of BR felt that instead of listening to all the advice that is given to the entrepreneur during $B R$ from external parties other than the BRP, the entrepreneur should focus on the business and do what they feel is in the best interest of the business. It appears that entrepreneurs who had a negative experience of BR as well as some who did not, learned about managing relationships through which guidance could be given to them, which is in line with Cope's (2011) findings of learning about the nature and management of relationships.

Lastly, overcoming the emotional hurdles associated with failure and overcoming the fear of failure was also noted as a valuable personal lesson that was learned during BR. One entrepreneur mentioned the importance of remaining positive and focussed during the rescue process. Similarly, Shepherd et al. (2007) found that although failure is financially costly to entrepreneurs, emotional costs dominate over financial costs. In line with this, Cope (2011) found that failure can have a negative impact on entrepreneurial risktaking propensity and self-efficacy.

Figure 4 summarises the personal learning of entrepreneurs during BR.

\section{Driving factors}

The factors that enabled entrepreneurs who had a positive experience of BR to learn about their business, the BR process and about themselves can be grouped into three broad categories, namely: factors related to the benefits of $\mathrm{BR}$, the $\mathrm{BRP}$ and the entrepreneur's own actions and background.

One of the driving factors that were identified by all the entrepreneurs in this group was 'sense of protection against creditor claims'. By not constantly having to deal with the stress of having to pay creditors, it was felt that the 
entrepreneurs could focus their energy and time on the business, which again enabled them to learn invaluable lessons about their business and themselves. This driving factor resonates the intention of the Act, namely to offer financially distressed businesses with the necessary time (moratorium) to reorganise their affairs and recuperate from their challenges.

The second driving factor that was identified by all the entrepreneurs who had a positive experience of BR was the fact that they trusted their BRPs. This attributed to a sense of safety and helped create a less tense environment in which the focus could be on rescuing the business and learning in doing so. The entrepreneurs' trust in the BRP was based on their perception of the BRP's financial, legal and management competence.

Another factor that enabled the group with a positive experience to learn not only about the process but also about the business was collaboration and constant communication with the BRP. There was a sense of working together towards the same goal. Knowledge and ideas were constantly shared between the entrepreneurs and the BRPs, who were always willing to make recommendations. The entrepreneurs relied on the BRP for guidance in terms of the BR proceedings as well as the managing of the business. The positivity that some BRPs introduced into the businesses also motivated the entrepreneurs. The active involvement of the BRP also contributed to an environment that was conducive to entrepreneurial learning. One entrepreneur mentioned that despite his BR fees adding to his struggling business' expenditures and his BRP wanting to hand the business back to the entrepreneur, the entrepreneur requested the BRP to stay, as he relied on their advice and guidance. As a result of the expertise of the BRPs and their willingness to listen and advise, some entrepreneurs saw value in the BRP's fees. They understood the BRP's role in assisting the business and were satisfied with the BRP's guidance and direction. The positive learning outcomes of collaboration between the entrepreneurs and the BRPs echo the work of Holman, Pavlica and Thorpe (1997), who argue that debate with oneself as well as collaboration with others forms the very basis of entrepreneurial learning.

The final factors that promote personal learning were centred on the entrepreneur. Some entrepreneurs felt that their education and previous business experience has enabled them to learn about their businesses during BR proceedings. Deliberate reflection and constant questioning about their business situations also marked a key difference between the entrepreneurs who had a positive experience of BR and learned about various aspects of the process, business and themselves and those who did not. Shepherd (2003) also found that entrepreneurs learn from failure when they reflect on the current information on why the business failed to revise their current knowledge about how to successfully manage a business. This finding also highlights the value of action learning in business failure, as were described by
McGill and Beaty (2001) and Watson (2004) as a process that includes action, deliberate reflection, generalisation and testing. Thus, deliberate reflection is a vital tool for extracting lessons from business failure which can change the way that entrepreneurs manage their businesses in the future.

\section{Restraining factors}

The circumstances around the BR cases of entrepreneurs who had a negative experience were notably different from those who had a positive experience of BR as the latter learned more. The key difference behind their experiences and the amount of content dimensions that they learned could be linked to the behaviour and actions of the BRP. This finding thus supports the work of Pretorius (2015, p. 78) which indicates that the BRP is a 'disproportionate influencer', as everything that is happening in the process can be connected to the BRP. The BRP thus to some extent 'moderates' the entrepreneurial learning environment during rescue.

One of the restraining factors to learning that often surfaced during the interviews with the subjects was that they did not trust the BRP. This finding is aligned to the liability of legitimacy which BRPs are faced with. Legitimacy relates to whether the BRP is of the perceived capacity to successfully affect the turnaround, given his or her credibility, reputation, knowledge, skills, track record, ability to muster resources, acceptability as a representative to all stakeholders and more (Pretorius \& Holtzhauzen, 2008). Noteworthy concerns regarding the BRP were the perceived incompetence of some of the BRPs as well as their alleged abuse of the proceedings. The seeming incompetence of BRPs mainly related to their inability to draft a BR plan that meets all stakeholder expectations. Some of the BR plans that were presented to creditors were described as merely being brief debt restructuring plans, which contained no actual plan to reorganise the affairs of the business. This is vital not only to get a majority vote but also to actually make the necessary adjustments to enable the business to be able to operate on a profitable basis again, instead of merely postponing creditor payments. After some of the BRPs already accepted their appointment, entrepreneurs were informed that if they cannot come up with the money to pay the creditors themselves, then there is no prospect to save the business. In one case, the BRP did not quantify votes when the BR plan was presented, as was prescribed by the Act. In another case, where the BRP failed to prepare a rescue plan, the BRP did not set up any creditors meetings and filed for liquidation before the first creditors meeting (Section 142 [2][b][i] of the Act states that the BRP can do so if he believes there is no reasonable prospect). The fact that there was no rescue plan in some cases not only made it difficult for entrepreneurs to secure post-commencement funding but also denied them a potentially valuable learning opportunity. If a comprehensive rescue plan was compiled by the BRP, the entrepreneur could have seen an evaluation of the current state of affairs of the business, reflect on what went wrong and also to think about how they can act differently in the future to avoid similar situations. 
Alleged abuse of BR proceedings by BRPs left some entrepreneurs with a very negative experience of BR and limited learnings about the process, the businesses and themselves. One entrepreneur applied to court to have two consecutive BRPs removed because of malpractice and also because the BRPs were never licensed by the CIPC, as is required by the Act. Other allegations that might be constituted as abuse of BR are the cases where BRPs accepted appointments based on their stated belief that there is reasonable prospect to save the business, charged the entrepreneur a deposit for their services and then immediately filed for liquidation even before setting up a first creditors meeting or preparing a rescue plan. This made two of the subjects very negative about BR proceedings, as they saw no value in the BRP fees and shifted their focus from working with the BRP to reorganise the affairs of the business and from learning by doing so.

The lack of active involvement in the business, perceived arrogance and lack of collaboration with the entrepreneurs further added to negative experiences of BR. Some BRPs preferred doing all the work themselves and did not involve or consult with the entrepreneurs. As we know that debate with oneself and collaboration with others forms the basis of entrepreneurial learning Holman et al. (1997), it can be argued that a lack of collaboration can hamper learning. Other BRPs did not get involved and also did not advise the entrepreneurs in terms of the daily operations and functions within the business. This, again, moved the entrepreneurs' attention from focussing on the business and learning to focus on the process and understanding their believed 'rights'.

The only restraining factor that was not related to the BRP was the entrepreneur's own lack of knowledge regarding their 'believed rights' in the BR process set out by the Act. Because of the newness of the Act and a general lack of knowledge on BR, very few entrepreneurs knew how BR should work, identify when there is possibly incompetence or abuse and what their perceived 'rights' and options are. Gribnitz and Applebaum (2014) however reported that filing directors have no rights under the Act. Some of the entrepreneurs argued that if they knew more about the BR process, they could have a better experience as well as a better outcome of BR.

\section{Practical implications}

\section{Contribution to entrepreneurial learning in the context of business rescue}

This research contributes practically to the South African body of knowledge on formal reorganisation procedures. Generic business failure has an impact on entrepreneurial learning through various elements mainly to do with the context and the individual (entrepreneur). Like turnaround situations where a TP is involved, formal BR adds the BRP as moderator and mediator to these relationships that influence learning. Figure 1 provides a guideline for BRPs, business management educators as well as the Regulator to better understand the factors that promote or prevent entrepreneurial learning.

The BRP was found to play an important role as both driver and hindrance to entrepreneurial learning in BR (similar to Pretorius [2016]) referring to it as a 'disproportionate influence'. Potentially, the BRP's reputation of 'skill transfer' may therefore serve as a future selection criterion to filing directors. Furthermore, it highlights the long-term invaluable learnings that BR can offer to businesses' management which may extend the potential of BR to positively influence the economy beyond the time frame of the proceedings, as entrepreneurs can apply their learnings in future situations. Educators may also benefit from the result as it serves as a directive for training programmes. Because of the nature of this study being exploratory, it primarily aims to direct future research into entrepreneurial learning under this newly instituted business recovery regime.

The findings contribute to an improved understanding of specific entrepreneurial learning content dimensions to guide future research. Second, it identified factors that may drive or restrain such learning and may be exploited by the Regulator and practitioners. Finally, this study proposes directives for education of both entrepreneurs and practitioners to optimise entrepreneurial learning under this newly instituted business recovery regime.

The study has added to learning during failure by exposing how negative experiences can significantly limit entrepreneurial learning during BR proceedings. Investigating learning in BR identified an additional context to be considered. Given the porousness of borders and the international cross-border rescue and insolvency procedures taking place, there is a definite need for widening the availability of knowledge obtained from this research. Potentially relevant to turnaround, it, however, requires further investigation before generalising its application. Alleged incompetence and abuse of the process by BRPs are rife in the industry (Pretorius, 2015, 2016), and subsequently in this study, a lack of trust in the BRPs was confirmed as the main reason why the entrepreneurs had a negative experience of BR, and thus did not learn as much as those with a positive experience. These restraining factors thus limit the long-term potential of entrepreneurial learning during BR proceedings. It is thus recommended that the Regulator investigates measures and avenues to address potential abuse and incompetence, by potentially assigning independent professional bodies who can take action on reports and complaints of BRP misconduct or incompetence. Although the CIPC as Regulator is the appointed responsible body for BR in South Africa, more aggressive action needs to be taken to eradicate malpractice to ensure that the novel intentions of the Act are achieved. The prescribed tasks of BRPs do not cover an obligation to address entrepreneurial learning but should recognise its importance for when 
$\mathrm{BR}$ is officially over and the entrepreneurs must take the reins again.

\section{Research limitations and future research recommendations}

This study is to some extent limited by restricted literature on the topic of BR, specifically in terms of entrepreneurial learning in this specific context. As the subjects were asked to share their personal experience, the potential risk of bias based on their background, social desirability and personal loss remains plausible (Saunders et al., 2009). In sense making, this is to be recognised (Weick, 1995) as it was their experiences of those involved, which were reported. The restrictions of individual in-depth interviews were recognised and mitigated as far as it was possible (Marshall \& Rossman, 2006; Ritchie \& Lewis, 2003).

It is acknowledged by the researchers that the number of subjects interviewed may limit the study, even though data saturation was reached after eight interviews. It is however acknowledged that each rescue has its own unique context and interpretation should consider this before any generalisation. Lastly, we acknowledge the fact that the study was subject to the researchers' own interpretations of the data was possibly a limitation. We also acknowledge that a relationship may exist between failed versus successful rescues influencing the entrepreneur's experience as positive or negative as well as the learning opportunities associated with each. Future research can look at this.

The academic literature related to BR remains scant and extensive studies on various aspects are still needed to better understand it. The findings of this study have uncovered a number of areas in which further research is needed. Specifically, more research is needed on the creation of an enabling environment within BR that is conducive to entrepreneurial learning. Finally, research should be conducted on malpractice and best practice for BRPs, as the weight of the long-term success of BR in South Africa largely rests on their shoulders.

\section{Conclusion}

Learning from business failure remains complex as it stretches the limits of entrepreneurial learning by adding distress to the context. Business rescue, as applied under South African legislation provides for a rescue practitioner that is considered an expert who can impart knowledge to those who must take the business back at substantial implementation. However, this research identified driving and restraining factors to learning that exist under the duress of the business rescue process.

\section{Acknowledgements Competing interests}

The authors declare that they have no financial or personal relationships that may have inappropriately influenced them in writing this article.

\section{Authors' contributions}

A.B-1.R. executed the research for MPhil degree purposes while M.P. conceptualised the problem. Collaborative effort was made for the appropriate design, theory and reviews.

\section{References}

Argenti, J. (1976). Corporate planning and corporate collapse. Long Range Planning, 9(6), 12-17. https://doi.org/10.1016/0024-6301(76)90006-6

Barker, V.L., III, \& Duhaime, I.M. (1997). Strategic change in the turnaround process: Theory and empirical evidence. Strategic Management Journal, 18(1), 13-38. https://doi.org/10.1002/(SICI)1097-0266(199701)18:1<13::AID-SMJ843>3.0.CO;2-X

Barker, V.L., III, \& Moné, M.A. (1998). The mechanistic structure shift and strategic reorientation in declining firms attempting turnarounds. Human Relations, 51(10), 1227-1258. https://doi.org/10.1177/001872679805101002

Berglund, H. (2007). Researching entrepreneurship as lived experience. In H. Neergaard \& J.P. Ulhøi (Eds.), Handbook of Qualitative research methods in entrepreneurship (pp. 75-93). Cheltenham: Edward Elgar.

Blackburn, R., \& Kovalainen, A. (2008). Researching small firms and entrepreneurship: Past, present and future. International Journal of Management Reviews, 11(2), 127-148. https://doi.org/10.1111/j.1468-2370.2008.00254.x

Burbank, R.K. (2005). The classic five-step turnaround process: Case study of ProdiGene, Inc. The Journal of Private Equity, 8(2), 53-58. https://doi.org/10.3905/ jpe.2005.490419

Cardon, M., \& McGrath, R.G. (1999). When the going gets tough...toward a psychology of entrepreneurial failure and re-motivation. Frontiers of Entrepreneurship Research, 29, 58-72.

Cochran, A.B. (1981). Small business mortality rates: A review of the literature. Journal of Small Business Management, 19(4), 50-59.

Cooper, D.R., \& Schindler, P.S. (2008). Business research methods. (11th edn.). New York: McGraw-Hill Higher Education.

Cope, J. (2005a). Toward a dynamic learning perspective of entrepreneurship. Entrepreneurship Practice and Theory, 29(3), 373-397. https://doi.org/10.1111/ j.1540-6520.2005.00090.x

Cope, J. (2005b). Researching entrepreneurship through phenomenological inquiry: Philosophical and methodological issues. International Small Business Journal, 23(2), 159-183. https://doi.org/10.1177/0266242605050511

Cope, J. (2011). Entrepreneurial learning from failure: An interpretative phenomenological analysis. Journal of Business Venturing, 26(6), 604-623. https://doi.org/10.1016/j.jbusvent.2010.06.002

Cork Committee. (1982). Insolvency law and practice, Cm 8558. London: HMSO.

Du Toit, L. (2012). Tax implications for business rescues in South African law. Unpublished master's thesis, University of Pretoria, Pretoria, South Africa.

Easterby-Smith, M.A., Thorpe, R., \& Lowe, A. (2002). Management research: An introduction. London: Sage.

Eisenhardt, K.M. (1989). Building theories from case study research. Academy of Management Review, 14(4), 532-550.

Ellis, S., Mendel, R., \& Nir, M. (2006). Learning from successful and failed experience: The moderating role of kind of after-event review. Journal of Applied Psychology, 91(3), 669-680. https://doi.org/10.1037/0021-9010.91.3.669

Fossey, E., Harvey, C., McDermott, F., \& Davidson, L. (2002). Understanding and evaluating qualitative research. Australian and New Zealand Journal of Psychiatry, 36(6), 717-732. https://doi.org/10.1046/j.1440-1614.2002.01100.x

Gioia, D.A., \& Chittipedi, K. (1991). Sensemaking and sensegiving in strategic change initiation. Stategic Management Journal, 12(6), 433-446. https://doi.org/10.1002/ smj.4250120604

Gribnitz, K., \& Applebaum, R. (2014). Business Rescue and Compromise offers - A practical analysis of the obligations and rights as set out in Chapter 6 of the Companies Act No 71 of 2008 as amended. (1st edn.). Johannesburg: G7A Compass Publishing (Pty) Limited.

Guest, G., Bunce, A., \& Johnson, L. (2006). How many interviews are enough?: An experiment with data saturation and variability. Field Methods, 18, 59-82. https:// doi.org/10.1177/1525822X05279903

Holman, D., Pavlica, K., \& Thorpe, R. (1997). Rethinking Kolb's theory of experiential learning: The contribution of social constructivism and activity theory. ManagementLearning, 28,135-148. https://doi.org/10.1177/1350507697282003

Huovinen, J., \& Tihula, S. (2007). Entrepreneurial learning in the context of portfolio entrepreneurship. International Journal of Entrepreneurial Behaviour and Research, 14(3), 152-171. https://doi.org/10.1108/13552550810874673

Hycner, R.H. (1985). Some guidelines for the phenomenological analysis of interview data. Human Studies, 8, 279-303. https://doi.org/10.1007/BF00142995

Klein, G., Moon, B., \& Hoffman, R.R. (2006). Making sense on Sensemaking 1 Alternative perspectives. IEEE Intellegent Systems, 21(4), 70-73. https://doi. org/10.1109/MIS.2006.75

Kloppers, P. (1999). Judicial management - A corporate rescue mechanism in need of reform. Stellenbosch Law Review, 10, 417-435.

Leedy, P.D., \& Ormrod, J.E. (2001). Practical research: Planning and design. (7th edn.). Upper Saddle River, NJ: Merrill Prentice Hall. 
Le Roux, I., \& Duncan, K. (2013). The naked truth: Creditor understanding of business rescue: A small business perspective. Southern African Journal of Entrepreneurship
and Small Business Management, 6(167), 57-74. https://doi.org/10.4102/ and Small Busine

Marshall, C., \& Rossman, G.B. (2006). Designing qualitative research. Thousand Oaks, CA: Sage.

McGill, I., \& Beaty, L. (2001). Action learning: A guide for professional management and education developmen. (2nd edn.). London: Kogan Page.

Patton, M.Q. (1990). Qualitative evaluation and research methods. London: Sage Publications.

Politis, D. (2008). Does prior start-up experience matter for entrepreneur's learning? A comparison between novice and habitual entrepreneurs. Journal of Small Business and Enterprise Development, 15(3), 472-489. https://doi. org/10.1108/14626000810892292

Politis, D., \& Gabrielsson, J. (2009). Entrepreneurs' attitudes towards failure: An experiential learning approach. International Journal of Entrepreneurial Behaviour and Research, 15(4), 364-383. https://doi.org/10.1108/13552550910967921

Pretorius, M. (2008). When Porter's generic strategies are not enough: Complementary strategies for turnaround situations. Journal of Business Strategy, 29(6), 19-28. https://doi.org/10.1108/02756660810917200

Pretorius, M. (2009). Defining business decline, failure and turnaround: A content analysis. Southern African Journal for Entrepreneurship and Small Business Management, 2(1), 1-16. https://doi.org/10.4102/sajesbm.v2i1.15

Pretorius, M. (2015). Business rescue status quo report: Final report. Hatfield: University of Pretoria.

Pretorius, M. (2016). The debtor-friendly fallacy in business rescue: Agency theory moderation and quasi relationships. Southern African Journal of Economics and Management Sciences, 19(4), 479-496.

Pretorius, M., \& Holtzhauzen, G. (2008). Critical variables of venture turnarounds: A liabilities approach. Southern African Business Review, 12(2), 87-107.

Pretorius, M., \& Holtzhauzen, G. (2013). Business rescue decision making through verifier determinants - Ask the specialists. South African Journal of Economic and Management Sciences, 16(4), 468-485.

Pretorius, M., \& Le Roux, I. (2011). Successive failure, repeat entrepreneurship and no learning: A case study. SA Journal of Human Resource Management/SA Tydskrif vir Menslikehulpbronbestuur, 9(1), 1-13. https://doi.org/10.4102/sajhrm.v9i1.236

Pretorius, M., \& Rosslyn-Smith, W. (2015). Stakeholder expectations of the business rescue plan from a South African perspective. Southern African Journal of Entrepreneurship and Small Business Management, 7(1), 1-35. https://doi. org/10.4102/sajesbm.v7i1.4

Ring, P.S., \& Rands, G.P. (1989). Sensemaking, understanding, and committing: Emergent interpersonal transaction processes in the evolution of 3M's microgravity research program. In A.H Van de Van, H.L. Angle, \& M.S. Poole (Eds.), Research on the management of innovation: The Minnesota studies (pp. 337-366). New York: Ballinger.

Ritchie, J., \& Lewis, J. (2003). Qualitative research practice: A guide for social science students and researchers. Thousand Oaks, CA: Sage.
Robbins, D.K., \& Pearce, J.A. (1992). Turnaround: Retrenchment and recovery. Strategic Management Journal, 13(4), 287-309. https://doi.org/10.1002/smj.4250130404

Sandberg, J., \& Tsoukas, B. (2015). Making sense of the sensemaking perspective: Its constituents, limitations, and opportunities for further development. Journal of Organizational Behavior, 36(Suppl 1), S6-S32. https://doi.org/10.1002/job.1937

Saunders, M., Lewis, P., \& Thornhill, A. (2009). Research methods for business students. London: Financial Times/Prentice Hall.

Senior, V., Smith, J.A., Michie, S., \& Marteau, T.M. (2002). Making sense of risk: An interpretive phenomenological analysis of vulnerability to heart disease. Journal of Health Psychology, 7(2), 157-168. https://doi.org/10.1177/1359105302007002455

Seymour, R.G. (2006). Hermeneutic phenomenology and international entrepreneurship research. Journal of International Entrepreneurship, 4(4), 137-155. https://doi org/10.1007/s10843-007-0011-5

Shepherd, D.A. (2003). Learning from business failure: Propositions of grief recovery for the self-employed. Academy of Management Review, 28(2), 318-328.

Shepherd, D.A., Douglas, E.J., \& Shanley, M. (2000). New venture survival: Ignorance, external shocks, and risk reduction strategies. Journal of Business Venturing, 15(5), 393-410. https://doi.org/10.1016/\$0883-9026(98)00032-9

Shepherd, D.A., Wicklund, J., \& Haynie, J.M. (2007). Moving forward: Balancing the financial and emotional costs of business failure. Journal of Business Venturing 28(2), 318-328.

Smith, J.A., \& Eatough, V. (2006). Interpretative phenomenological analysis. In G.M Breakwell, S. Hammond, C. Fife-Schan, \& J.A. Smith (Eds.), Research methods in psychology (pp. 322-341). London: Sage.

Smith, J.A., Jarman, M., \& Osborn, M. (1999). Doing interpretative phenomenological analysis. In M. Murray \& K. Chamberlain (Eds.), Qualitative health psychology (pp. 218-239). London: Sage.

Smith, J.A., \& Osborn, M. (2008). Interpretative phenomenological analysis. In J.A Smith (Ed.), Qualitative psychology: A practical guide to research methods. (2nd edn.). London: Sage.

Walsh, G.S., \& Cunningham, J.A. (2016). Business failure and entrepreneurship: Emergence, evolution and future research. Foundations and Trends ${ }^{\otimes}$ in Entrepreneurship, 12(3), 163-285. https://doi.org/10.1561/0300000063

Watson, G.E.H. (2004). A situational analysis of entrepreneurship mentors in South Africa. Unpublished M Com thesis, University of Pretoria, Pretoria, South Africa. Retrieved June 14, 2015, from Unisa ETD: http://umkn-dsp01.unisa.ac.za/ bitstream/handle/10500/2098/dissertation.pdf?sequence=1

Weick, K.E. 1995. Sensemaking in organisations. (Vol 3). Newbury Park, CA: Sage.

Westbrook, J.L. (2010). A global view of business insolvency systems. Washington, DC: Martinus Nijhoff.

Wickam, P.A. (2000). Strategic entrepreneurship: A decision-making approach to new venture creation and management. (4th edn.). London: Pitman.

Yanow, D. (2004). Translating local knowledge at organizational peripheries. British Journal of Management, 15(1), 9-25. https://doi.org/10.1111/j.1467-8551.2004. t01-1-00403.x

Yin, R.K. (2003). Case study research: Design and methods. Thousand Oaks, CA: Sage. 